13. Shevtsov I. I. Pokhidni 2-oksoindolin-3-hlioksylovoi kysloty-potentsiini rehuliatory sechovydilnoi funktsii nyrok : Abstract's PhD thesis. Kharkiv, 2006. 20 p.

14. Klinichni biokhimiia / ed. by Tymoshenko O. P. et. al. Kharkiv: Vyd-vo "Profesional", 2005. 288 p.

15. Kamyshnikov V. S. Spravochnik po kliniko-biokhimicheskoy laboratornoy diagnostike. Vol. 1. Minsk: Belarus, 2000. $495 \mathrm{p}$.

16. Lapach S. N., Chubenko A. V., Babich P. N. Statisticheskie metody v mediko-biologicheskikh issledovaniyakh $\mathrm{s}$ ispol'zovaniem EXEL. Kyiv: MORION, 2001. 408 p.

17. Comparative Studies on Polyphenolic Composition, Antioxidant and Diuretic Effects of Nigella sativa L. (Black Cumin) and Nigella damascena L. (Lady-in-a-Mist) Seeds / Toma C.-C. et. al. // Molecules. 2015. Vol. 20, Issue 6. P. 9560-9574. doi: http://doi.org/10.3390/molecules20069560

Дата надходження рукопису 12.06.2018

Anna Markina, Senior Laboratory, Department of Clinical Pharmacology, Institute of Pharmacy Professionals Qualification Improvement, National University of Pharmacy, Zahysnynykiv Ukrainy sq., 17, Kharkiv, Ukraine, 61001

Oksana Mishchenko, Doctor of Pharmaceutical Sciences, Professor, Head of Department, Department of Clinical Pharmacology, Institute of Pharmacy Professionals Qualification Improvement, National University of Pharmacy, Zahysnynykiv Ukrainy sq., 17, Kharkiv, Ukraine, 61001

E-mail: mishchoksana@gmail.com; clinpharmacol_ipksph@nuph.edu.ua

УДК 543.422.3:615.4

DOI: 10.15587/2519-4852.2018.141397

\title{
DEVELOPMENT AND VALIDATION OF SPECTROPHOTOMETRIC METHOD FOR THE DETERMINATION OF MELDONIUM DIHYDRATE IN DOSAGE FORMS
}

\author{
(C) A. Donchenko, N. Nahorna, S. Vasyuk
}

Мета. Спектрофотометрія є одним із найбільи широко застосовуваних методів у фармацевтичному аналізі. Висока чутливість, економічність та доступність для більиості лабораторій контролю якості лікарських засобів є безперечними перевагами изього абсорбиійного методу. Однак існує необхідність пошуку нових аналітичних реагентів для розробки методик кількісного визначення. Тому метою роботи стало дослідження взаємодї мельдонію дигідрату з n-хлоранілом та розробка на основі отриманих даних спектрофотометричної методики аналізу препарату в лікарських формах.

Методи. В дослідженні використовували робочий стандартний зразок мельдонію дигідрату, n-хлораніл, ДМФА, зразки готових лікарських форм. Для визначення оптичної густини продуктів реакиії застосовували спектрофотометр Sресогd 200.

Результати. В ході розробки методики були підібрані оптимальні умови проведення спектрофотометричного аналізу. Досліджено вплив на перебіг реакції таких чинників як природа розчинника, концентраиія реагенту, температура та час нагрівання. Експериментально встановлено, ияо мельдоній взаємодіє з п-хлоранілом у середовищі ДМФА з утворенням забарвленої сполуки з максимумом абсорбиї при 556 нм. Проведено валідацію розробленої методики. Визначено основні валідаційні характеристики, а саме, лінійність, прецизійність, правильність, робасність та діапазон застосування. Підпорядкування закону Бера спостерігається в межах концентрацій 8,00-20,00 мг/100 мл, коефіцієнт кореляції становить 0,9995. Параметри лінійної залежності розраховано за допомогою регресійного аналізу методом найменших квадратів. Запропонована методика відповідає вимогам ДФУ, які висувають до методик кількісного аналізу лікарських речовин.

Висновки. Розроблено та валідовано спектрофотометричну методику кількісного визначення мельдонію дигідрату, яка успішно застосована для аналізу лікарських форм. Результати дослідження свідчать, щуо методика є точною, простою у виконанні та придатною для використання в лабораторіях контролю якості лікарських речовин

Ключові слова: спектрофотометрія, похідні хінону, п-хлораніл, мельдонію дигідрат, аналіз, кількісне визначення, валідація

\section{Introduction}

Today, metabolic therapy is an important component of the treatment of virtually any disease of the internal organs. Drugs affecting the metabolic processes in the heart, brain, liver, muscles, are widely prescribed by general practitioners and narrow specialists. A special place among them take cardioprotectors - a group of drugs that improves metabolic processes in ischemic myocardium, increase resistance to hypoxia, eliminate cellular metabolism disorders. To the well-known and recognized by clinicians cardioprotectors also belongs meldonium [1]. The drug was created at the Latvian Institute of Organic Synthesis in the mid-1970s and was used as a veterinary product. In clinical practice meldo- 
nium began to be applied only later, after detecting cardioprotective properties of it [2].

\section{Formulation of the problem in a general} way, the relevance of the theme and its connection with important scientific and practical issues

Meldonium is a structural analogue of gammabutyrobetamine. At the heart of the mechanism of action of the drug is the reduction in the amount of carnitine in the body, which in the conditions of oxygen insufficiency leads to inhibition of oxidation of fatty acids. Meldonium induces biosynthesis of nitric oxide, which promotes relaxation of smooth muscle of vessels, improves microcirculation and endothelial function [3]. The therapeutic effect of the drug is due to the variety of its pharmacological effects. Meldonium is used in the treatment of various chronic cardiovascular diseases and disorders of the cerebral circulation, as well as to improve mental and physical capacity [4]. Pharmaceuticals based on it are manufactured by leading domestic and foreign pharmaceutical companies in the form of tablets, capsules and injection solutions. Consequently, there is a need to ensure the control of their quality by developing reliable and affordable methods of pharmaceutical analysis of meldonium in medicinal forms.

\section{Analysis of recent studies and publications in} which a solution of the problem are described and to which the author refers

The substance meldonium dihydrate is described in the European Pharmacopoeia and the State Pharmacopoeia of the Russian Federation (SPRF) [5, 6]. Thus, the SPRF XII recommends the quantitative determination of meldonium dihydrate by the acidimetry method in a nonaqueous medium with a potentiometric fixation of the end point of titration. To date, in the scientific literature there is a considerable number of works devoted to the analysis of meldonium dihydrate in biological fluids. For example, Chinese scientists from the Fourth Military Medical University have proposed a HPLC method with tandem mass spectrometry detection for the quantitative determination of meldonium in human plasma [7]. The chromatographic technique was also used by Ukrainian scientists to study the bioequivalence of oral meldonium [8]. However, there is almost no data on the analysis of dosage forms. There is a well-known method for the determination of choline alphospherate and meldonium for their co-presence in a solution using micellar electrokinetic chromatography under conditions of indirect detection [9].

\section{The field of research considering the general problem, which is described in the article \\ In the development of spectrophotometric meth-} ods of analysis, the general problem is the search for reagents that allow carrying out quantitative determination of active pharmaceutical ingredients precisely, expressively and economically. Among the organic reagents the quinone derivatives deserve special attention. Quinones are available on the Ukrainian market of chemical reagents, and reactions of their use are characterized by high specificity, selectivity and sensitivity. Therefore, it is promising to study the interaction of derivatives of quinone with medicinal substances and to develop on the basis of obtained data spectrophotometric methods for the determination of pharmaceuticals.

\section{Formulation of goals (tasks) of article}

The aim of the work was to develop precise and economical spectrophotometric methods for quantitative determination of meldonium dihydrate in dosage forms on the basis of the reaction with p-chloranil and validation of the developed method in accordance with the requirements of the State Pharmacopoeia of Ukraine (SPHU).

8. Presentation of the main research material (methods and objects) with the justification of the results

For the study, sample of a working standard of meldonium dihydrate (series 250516, PAT "Farmak", Ukraine) and drugs - capsules "Vazonat" $250 \mathrm{mg}$ (series 80517, AT "OLANFARM", Latvia), a solution for injections "Vazonat "100 mg / ml (series 10417, AT "OLANFARM ", Latvia).

As a reagent and solvent were used p-chloranil, DMF and purified water.

Analytical equipment: spectrophotometer Specord 200, electronic scales ABT-120-5DM, water bath Memmert WNB 7-45, measuring glassware of class A.

\section{of meldonium dihydrate \\ General method for quantitative determination \\ The exact weighting of meldonium dihydrate} $(0.0350 \mathrm{~g})$ was placed in a volumetric flask of $25.00 \mathrm{ml}$, dissolved in $2.50 \mathrm{ml}$ of purified water and added to the mark with DMF, carefully mixed. $1.00 \mathrm{ml}$ of the final solution was treated with $0.50 \mathrm{ml}$ of $1 \% \mathrm{p}$-chloranil solution, stirred. The resulting reaction mixture was heated for 20 minutes in a water bath at a temperature of $95^{\circ} \mathrm{C}$. After cooling, the solution was transferred quantitively in a volumetric flask of $10.00 \mathrm{ml}$ and brought to the mark with a solution of DMF. The absorption was measured on the background of the compensating solution that did not contain the test substance at $556 \mathrm{~nm}$.

Method of quantitative determination of meldonium dihydrate in capsules

The exact weight of the capsule mass $(0.0380 \mathrm{~g})$ was placed in a volumetric flask of $25.00 \mathrm{ml}$, dissolved in $2.50 \mathrm{ml}$ of purified water and adjusted to DMF. The resulting solution was stirred and filtered, dropping the first portions of the filtrate. Further, the filtrate aliquots were analyzed according to the general procedure.

Method for quantitative determination of meldonium dihydrate in a solution for injections

$1.00 \mathrm{ml}$ of the solution for injections was placed in a $100.0 \mathrm{ml}$ volumetric flask and adjusted to a mark with DMF, mixed thoroughly. The aliquots of the resulting solution were analyzed according to the general procedure.

\section{Results and discussion}

As a result of the studies, it was found that meldonium dihydrate reacts with p-chloranil in a DMF medium to form a coloured compound with a maximum absorption of $556 \mathrm{~nm}$ (Fig. 1). The detection limit for optimum conditions is $10.22 \mu \mathrm{g} / \mathrm{ml}$. 


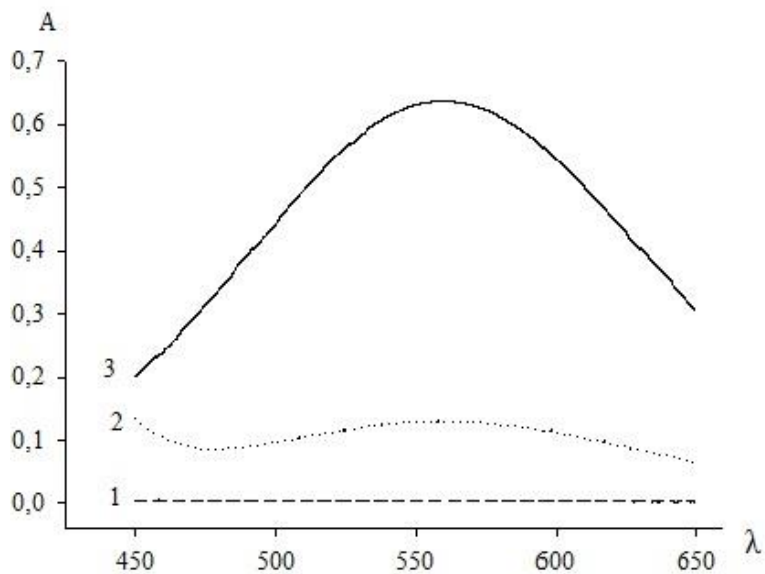

Fig. 1. Absorption spectrum of meldonium dihydrate (1), p-chloranil (2) and product of the reaction of meldonium dihydrate with p-chloranil (3) (meldonium dihydrate: $0.14 \%$, p-chloranil: $1 \%$, heating temperature: $95^{\circ} \mathrm{C}$, heating time: 5 min.)

During the development of the method, the study of the interaction of meldonium dihydrate with $\mathrm{p}$ chloranil was carried out. The factors that could influence the speed and completeness of the reaction, namely the nature and composition of the solvent, the concentration of the reagent, the temperature and stability of the reaction products in time, were studied.

When choosing a solvent, the solubility of meldonium dihydrate and p-chloranil was taken into account as well as the maximum value of the absorbance of the test solution. Thus, DMF was chosen as the most suitable solvent for the analysis. Also, to dissolve weighted amount of meldonium dihydrate $10 \%$ of the volume of purified water was added.

Further studies were carried out on the influence of temperature and time of heating on the value of absorbance (Fig. 2, 3). Experimentally it was established that the absorption maximum is observed when the reaction mixture is heated for 20 minutes at a temperature of $95{ }^{\circ} \mathrm{C}$.

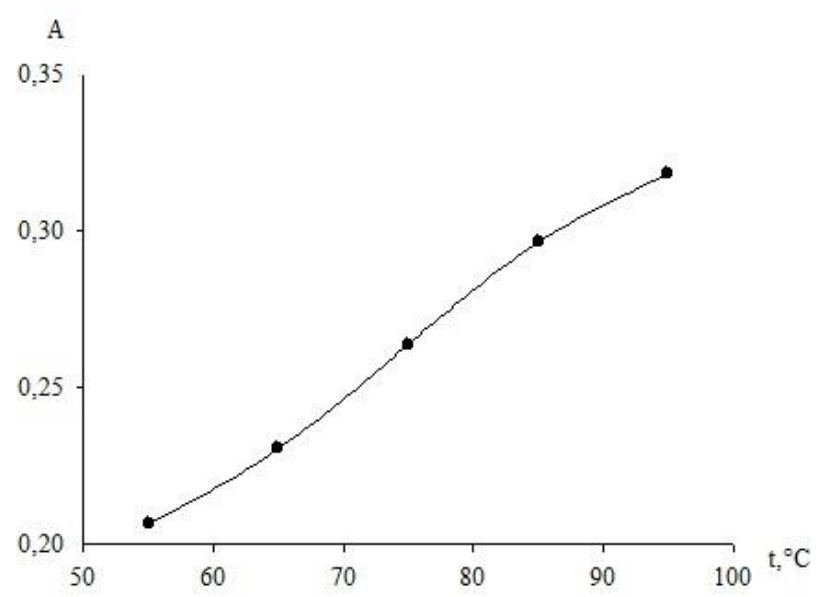

Fig. 2. Effect of temperature on the reaction of meldonium dihydrate with p-chloranil (meldonium dihydrate: $0.1 \%$, p-chloranil: $1 \%$, heating time: $5 \mathrm{~min}$ )

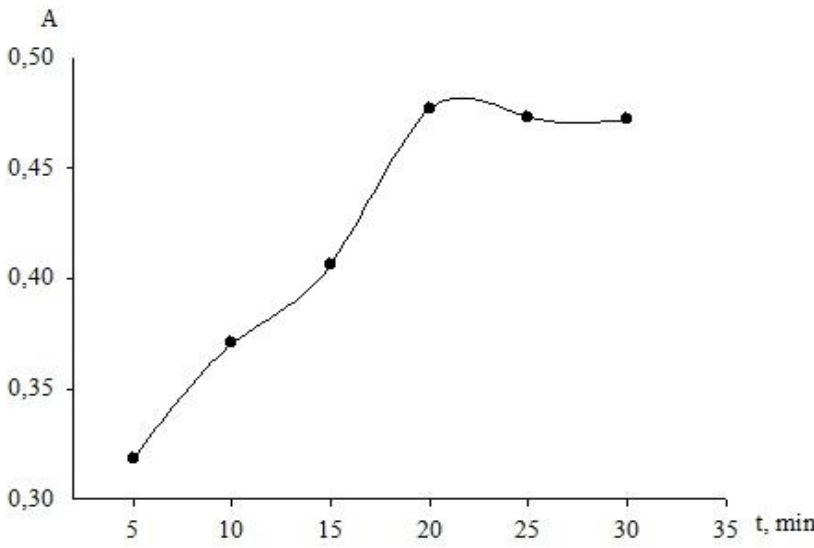

Fig. 3. Effect of heating time on the reaction of meldonium dihydrate with $\mathrm{p}$-chloranil (meldonium dihydrate:

$0.1 \%$, p-chloranil: $1 \%$, heating temperature: $95^{\circ} \mathrm{C}$ )

\section{Validation of the analytical method}

According to the requirements of the SPHU, validation of the developed methodology was carried out $[10,11]$. The main validation characteristics, namely linearity, precision, accuracy, robustness and range of application, are established according to standardized procedure by the standard method.

\section{Linearity}

To determine the linearity, 9 measurements of the absorption of working standard solution of meldonium dihydrate were performed in the range of concentrations in which the obedience of a Beer's law was observed, namely $8.00-20.00 \mathrm{mg} / 100 \mathrm{ml}$.

The calibration graph of the absorption from meldonium dihydrate concentration was plotted according to the obtained data (Fig. 4).

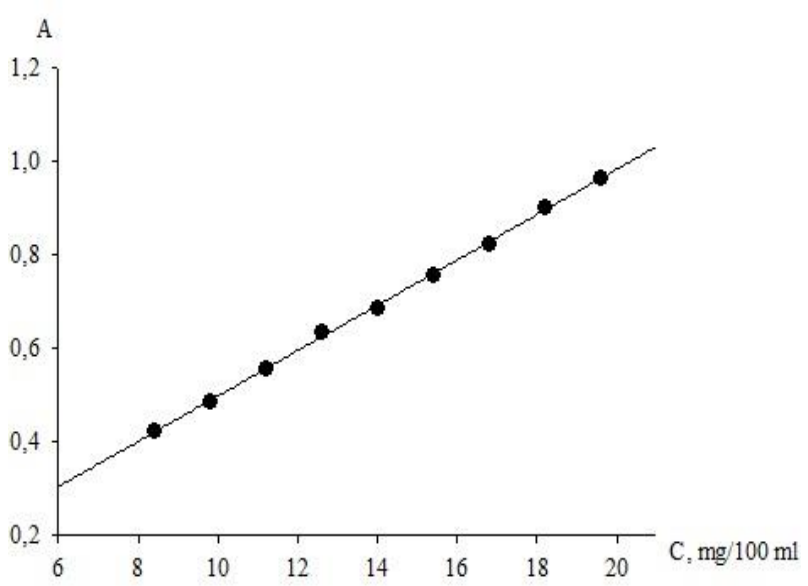

Fig. 4. Calibration curve of meldonium dihydrate

Parameters of linear dependence were calculated using regression analysis using the least squares method. The obtained values are given in Tab. 1

According to tab. 1 the requirements for linear dependence parameters are met, that is, the linearity of the method of quantitative determination of meldonium dihydrate is confirmed throughout the range of concentrations (60-140\%). 
Numerical indicators of linear dependence

\begin{tabular}{|c|c|c|c|}
\hline Figure & Value & Criteria & Conclusion \\
\hline$b \pm\left(s_{b}\right)$ & $0.0485 \pm(0.0006)$ & - & - \\
\hline$a \pm\left(s_{a}\right)$ & $0.0129 \pm(0.0081)$ & $|a| \leq \Delta a=t(95 \% ; 7) \cdot s_{a}=0.0153$ & corresponds \\
\hline$s_{x, 0}(\%)$ & 0.1257 & $\leq \Delta_{A s}(\%) / t(95 \% ; 7)=1.055$ & corresponds \\
\hline$r$ & 0.9995 & $\geq 0.9992$ & corresponds \\
\hline
\end{tabular}

\section{Precision}

Precision was determined at the level of repeatability. 9 samples were analyzed, the concentrations of which were evenly distributed in the investigated range of the technique (plus a comparison solution whose concentration was close to the nominal value).
According to the requirements of the SPHU to precision, the technique is accurate at the level of repeatability if the one-way confidence interval $\left(\Delta_{z}\right)$ does not exceed the maximum permissible uncertainty of the analysis $\left(\Delta_{\mathrm{AS}} \%\right)$. Data in Tabl. 2 testify the precision of the developed method.

Table 2

Precision determination results for meldonium dihydrate dosage forms $(n=9, p=0.95)$

\begin{tabular}{|l|c|c|c|c|}
\hline \multirow{2}{*}{ Dosage form } & \multicolumn{4}{|c|}{ Metrological characteristics } \\
\cline { 2 - 5 } & $\bar{Z} \%$ & $\Delta \%$ & $\Delta_{\mathrm{z}}$ & $\Delta_{A S} \%$ \\
\hline Capsules "Vazonat" & 100.16 & 0.73 & 1.36 & 1.6 \\
\hline Solution for injections "Vazonat" & 100.41 & 0.71 & 1.32 & 1.6 \\
\hline
\end{tabular}

\section{Accuracy}

To establish the accuracy of the developed method, the method of additives was used. During the experiment, known trials of the corresponding samples of the appropriate dosage form were added to the standard solution of meldonium dihydrate $(n=9)$. Then the absorption of the obtained solutions was measured. The accuracy of the technique was evaluated as the ratio entered / found. The results of the definitions are correct, since there is no significant systematic error, that is, the true value of the determined value falls into the established confidence interval [12]. The obtained values are given in Table 3.

Table 3

Accuracy determination results for meldonium dihydrate dosage forms

\begin{tabular}{|l|c|c|c|c|}
\hline \multicolumn{1}{|c|}{ Dosage form } & $\bar{Z} \%$ & $\Delta \%$ & $\Delta_{\mathrm{z}}$ & $\delta \%$ \\
\hline Capsules "Vazonat" & 100.40 & 1.78 & 3.31 & 0.40 \\
\hline Solution for injections "Vazonat" & 100.17 & 1.12 & 2.08 & 0.17 \\
\hline
\end{tabular}

\section{Robustness}

During the check of robustness, the influence of time on the stability of the investigated solutions was investigated. For this purpose, the absorption of the investigated solution of the appropriate dosage form $\left(\mathrm{A}_{1}\right.$ for capsules "Vazonat", $A_{2}$ for a solution for injections "Vazonat") and standard solution of meldonium dihydrate $\left(\mathrm{A}_{0}\right)$ was measured every 15 minutes for 1 hour (Table 4).
According to Tab. $4, \Delta_{\mathrm{t}} \% \leq \max \delta, \%$, so the solutions of dosage forms and standard solution of meldonium dihydrate are stable for 1 hour.

The obtained results indicate the prospect of further research on the interaction of quinone derivatives, namely p-chloranil, with active pharmaceutical ingredients and the relevance of development on the basis of obtained data of spectrophotometric methods for determination of pharmaceuticals.

Table 4

Results of determination of robustness

\begin{tabular}{|c|c|c|c|c|c|c|c|c|c|}
\hline $\mathrm{t}, \min$ & 0 & 15 & 30 & 45 & 60 & Mean & $\mathrm{RSD}, \%$ & $\Delta_{\mathrm{t}} \%$ & $\max \delta, \%$ \\
\hline $\mathrm{A} 0$ & 0.6842 & 0.6847 & 0.6861 & 0.6840 & 0.6831 & 0.6844 & 0.160 & 0.34 & \\
\hline $\mathrm{A} 1$ & 0.6880 & 0.6877 & 0.6872 & 0.6865 & 0.6853 & 0.6869 & 0.158 & 0.33 & 0.51 \\
\hline $\mathrm{A} 2$ & 0.6857 & 0.6862 & 0.6871 & 0.6854 & 0.6833 & 0.6856 & 0.208 & 0.44 & \\
\hline
\end{tabular}

9. Conclusions from the conducted research and prospects for further development of this field

1. According to the obtained data, precise and economical spectrophotometric method of quantitative determination of meltedonium dihydrate by the reaction with p-chloranil has been developed.

2. Validation of the developed method is carried out. The main validation characteristics, namely linearity, precision, accuracy, robustness and range of application, are established according to standardized procedure by the standard method.

3. It has been proved that the technique is suitable for use in laboratories for quality control of drugs and technical control departments of chemical and pharmaceutical enterprises. 


\section{References}

1. Prykhodko Yu. V., Kashkovskyi D. O., Prykhodko V. M. Metabolichna terapiia v praktytsi simeinoho likaria. Znachennia metabolichnykh preparativ v heriatrychnii klinitsi // Semeinaia medytsyna. 2015. Issue 1 (57). P. 7-16.

2. Gorbunova A. A., Kireev S. Yu., Rashevskaya I. V. Mel'doniy: svyaz' stroeniya, struktury i svoystv // Vestnik Penzenskogo gosudarstvennogo universiteta. 2017. Issue 2 (17). P. 92-99.

3. Dzerve V. Ya., Kalvinsh I. Ya. Mildronat v kardiologii. Obzor issledovaniy. Riga, 2013. 76 p.

4. MEL'DONIY (MELDONIUM). Opisanie aktivnykh veshhestv // Spravochnik Kompendium. URL: https://compendium. com.ua/akt/77/2984/meldonium/

5. Gosudarstvennaya farmakopeya Rossiyskoy Federatsii. XII-izd. Moscow: Izdatel'stvo «Nauchnyy tsentr ekspertizy sredstv meditsinskogo primeneniya», 2008. $704 \mathrm{p}$.

6. European Pharmacopoeia. 8.3th ed. Strasbourg: European Department for the Quality of Medicines, 2015. 4378 p.

7. Determination of mildronate by LC-MS/MS and its application to a pharmacokinetic study in healthy Chinese volunteers / Peng Y. et. al. // Journal of Chromatography B. 2010. Vol. 878, Issue 5-6. P. 551-556. doi: http://doi.org/10.1016/j.jchromb. 2009.12.030

8. Pidpruzhnykov Y. V., Sabko V. E., Iurchenko V. V., Zupanets I. A. UPLC-MS/MS method for bioequivalence study of oral drugs of meldonium // Biomedical Chromatography. 2011. Vol. 26, Issue 5. P. 599-605. doi: http://doi.org/10.1002/bmc.1703

9. Razrabotka metodiki kolichestvennogo opredeleniya kholina al'fostserata i mel'doniya metodom kapillyarnogo elektroforeza / Gavrilin M. V. et. al. // Voprosy biologicheskoy, meditsinskoy i farmatsevticheskoy khimii. 2012. Issue 4. P. 12-17.

10. Derzhavna Farmakopeia Ukrainy. Vol. 1. Kharkiv: Derzhavne pidpryiemstvo «Naukovo-ekspertnyi farmakopeinyi tsentr», 2015. $1128 \mathrm{p}$.

11. Ermer J. Method Validation in Pharmaceutical Analysis: A Guide to Best Practice. Weinheim: Wiley-VCH., 2015. 440 p.

12. Grizodub A. I. Standartizovannye protsedury validatsii metodik kontrolya kachestva lekarstvennykh sredstv. Kharkiv: Gosudarstvennoe predpriyatie «Ukrainskiy nauchnyy farmakopeynyy tsentr kachestva lekarstvennykh sredstv», 2016. 396 p.

Дата надходження рукопису 26.07.2018

Donchenko Anastasiia, Postgraduate student, Department of Analytical Chemistry, Zaporizhzhia State Medical University, Maiakovskoho ave., 26, Ukraine, Zaporizhzhia, 69035

E-mail: donchenko130791@gmail.com

Nahorna Natalia, PhD, Senior Lecturer, Department of Analytical Chemistry, Zaporizhzhia State Medical University. Maiakovskoho ave., 26, Ukraine, Zaporizhzhia, 69035

E-mail: natalija.nagornaja@gmail.com

Vasyuk Svitlana, Doctor of Pharmaceutical Sciences, Professor, Head of Department, Department of Analytical Chemistry. Zaporizhzhia State Medical University, Maiakovskoho ave., 26, Ukraine, Zaporizhzhia, 69035

E-mail: svitlanavasyuk@gmail.com 